\title{
PROMISE FREEDOM TO INDIA AFTER WAR WITH JAPAN
}

\author{
Bertrand Russell
}

INTRODUCTION BY ANDREW G. BONE

The text presented below showcases a recently unearthed report, in the first person, of a speech delivered by Russell to the Cambridge Majlis on 6 March

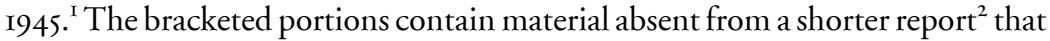
has long been known to exist. The textual differences between the two versions are quite interesting, and attention is briefly drawn to them below.

The Cambridge Majlis was a university club and debating society set up for Indian students in I89I and often addressed by prominent supporters of India's independence - both from the ranks of the indigenous nationalist movement and its left-wing allies in Britain. As a former chair (from 1930 to 1939) of the India League, the anti-colonial campaign's British arm, it was perfectly natural for Russell to have received an invitation to speak. Only the previous year he had described himself as "a life-long friend of Indian freedom". ${ }^{3}$ Yet the sincerity of Russell's commitment to this cause had been questioned during wartime as his views on India had moved into surprisingly close alignment with those of a British government led by that diehard upholder of the Raj, Winston Churchill. ${ }^{4}$ Britain's official policy had been encapsulated early in 1942 in the "Cripps

I "Promise Freedom to India after War with Japan”, Bombay Chronicle, Io March 1945; reprinted in Towards Freedom: Documents on the Movement for Independence in India 1945, ed. Bimil Prasad (India Council of Historical Research; New Delhi: Oxford U. P., 2008), pp. 228-9.

2 "Bertrand Russell on Indian Freedom", The Modern Review, Calcutta, 77, no. 4 (April 1945): 147.

3 "My Program for India", Common Sense I3 (Feb. 1944): 51.

${ }^{4}$ Less than a month before Russell's Cambridge speech, for example, the Bombay Sentinel had published an editorial highly critical of him: "Revival of Cripps Plan Not a Solution", 7 Feb. 1945; reprinted in Towards Freedom, pp. 136-8. See also Russell's exchanges with the American writer Louis Fischer, a future biographer of Gandhi, in " 'What about India?" ", The American Forum of the Air, Washington, D.C., 4, no. 4I (II Oct. 1942): 7-13. 
offer" (to which Russell referred in Cambridge) of full independence after the war combined with "opt-out" entitlements for India's Muslim majority provinces. ${ }^{5}$ In return, Indian nationalists were asked for their full backing of the Allied war effort. But the Congress Party refused to accept a deal that took no immediate steps towards dismantling the Raj while also raising the spectre of freedom without unity. To force the issue, Gandhi launched a "Quit India" campaign, which resulted in the internment of hundreds of Congress leaders and violent protests against this repression. Russell disliked the resort to coercion, but despaired that civil disobedience was only "likely to assist India's enslavement" by Japan, whose rampant militarism, in his judgment, posed a far more serious threat to Indian freedom than the last gasps of British imperialism. ${ }^{6}$

Having jettisoned the pacifist politics to which he had adhered for much of the I930s, Russell would brook no obstacle to the vigorous pursuit of war against the Axis powers. Regarding the Cripps offer as reasonable and sincere, he lamented its rejection and was dismayed at the questioning of Britain's motivesespecially by American liberals fearful that their country had been drawn into a conflict for the preservation of the British Empire. Most of his previous wartime writings on India had been directed at this influential current of opinion in the United States (where he was living) in order to show that Churchillian imperialism had become an anachronism and that Indian self-government would not be postponed indefinitely but merely delayed for the duration of the war. ${ }^{7}$ Recent historiography, ${ }^{8}$ however, implies that Russell was over-confident in these assumptions. Churchill regarded the Cripps mission as a sop to the United States and conspired from the outset with Viceroy Linlithgow to undermine it. The British Prime Minister's “apparent acceptance of the inevitability of India's achievement of independence was largely a device, disguising a deep-rooted

5 The Labour politician Sir Stafford Cripps (I889-I952) had led the British mission that arrived in Delhi in March 1942. A senior member of the War Cabinet who had emerged as something of a rival to Churchill, Cripps was also (like Russell) a longstanding supporter of India's political aspirations whose sympathies had been muted temporarily by the more urgent priority of winning the war.

6 "Gandhi's Stand Disapproved" (letter to ed.), New York Times, 5 Aug. 1942, p. I8. See also "To End the Deadlock in India", Asia 42 (June 1942): 338-40.

7 See above, n. 6, and "Bertrand Russell Writes of India, Britain, and the U.s.A." (letter to ed.), PM, New York, 20 Oct. 1942, p. I5; and "The International Significance of the Indian Problem", Free World, New York, 5 (Jan. 1943): 63-9. The two last items were co-signed by Patricia Russell.

${ }^{8}$ P. J. Cain and A. G. Hopkins, British Imperialism: Crisis and Deconstruction, I9I41990 (London and New York: Longman, 1993), p. I95 and n.85. 
inclination to hold onto India for as long as possible."

As Russell addressed the Cambridge Majlis in the early spring of 1945 , the Allied victory which had seemed so doubtful three years previously was almost in sight, and the protracted strains of a global conflict had undercut those who would have exploited the war to perpetuate British paramountcy in India. By this later date Russell was prepared to go somewhat further than the spurned Cripps offer and recommended an "unequivocal, definite and unambiguous" declaration, to be issued immediately, that British rule would cease twelve months after the end of the war. There was more in his speech to restore the slightly tarnished lustre of his image as a "friend of India", especially in the shorter, more sanitized report of it in The Modern Review: "It is for Indians themselves to settle their differences"; "[ $t$ ] he idea that India should become a dominion is futile and quite contrary to her geographical necessity"; "[ $t]$ he era of White domination will not last." The longer version (in the Bombay Chronicle) urges Indian political prisoners to be released but only on strict conditions, and makes another contentious - but very Russellian — call likely to antagonize Indian nationalists, namely, for an international authority to intercede in any prospective Indian civil war. ${ }^{\mathrm{IO}}$ Aside from the latter statement and a vague reference to "differences in India", there is nothing on the ferociously complex politics and demographics of Indian communalism. This was odd because Russell had written frankly and penetratingly elsewhere ${ }^{\mathrm{II}}$ about the prospect (and legitimacy) of a partition that now appeared increasingly likely owing to wartime promises made to Indian Muslims as quid pro quo for their loyal participation in the war against Japan. For the benefit of his student audience, however, Russell may have felt disinclined to challenge the deeply ingrained Congress assumption that the statehood of an independent India must be unitary.

Russell's wartime disagreements with Indian nationalists proved fleeting. $\mathrm{He}$ had, after all, been a stalwart champion of their goals for more than a quarter century, and he soon became a firm, but never uncritical, ${ }^{12}$ friend of the independent but partitioned state that came (bloodily) into existence in August 1947.

${ }^{9}$ Dennis Judd, The Lion and the Tiger: the Rise and Fall of the British Raj (Oxford: Oxford U. P., 2004), p. 156.

${ }^{\text {Io } I n}$ other writings, Russell speculated that an international commission of American, Soviet, Chinese, French and British delegates might also assist in the framing of an Indian constitution. See, for example, "The Future in India", manuscript, n.d. (I944?) (RAI 220.018060; forthcoming in Papers 24).

II Ibid., and, especially, "International Significance of the Indian Problem", p. 65.

${ }^{12}$ See especially Unarmed Victory, Chap. 3. 
TEXT ASCRIBED TO BERTRAND RUSSELL

W e are all agreed that it is impossible to keep up our position in India. Even if it is possible it is neither justified nor desirable. [Of course in a war people have to surrender their liberties as we have done in this country. That also applies to India but』as soon as we have got a Government of the people with liberal-mindedness, we can demand that we want a change for the better in India and set to work for that change. I know of the Cripps offer, I know it is still there. I know the offer of Dominion Status as soon as the war is over. But it is not what we want to do. The question is what Indians want. At any rate it is felt by a vast majority of Indians and by many other people, especially by the people of the United States, that our promise is not honest, that we do not mean to keep our ${ }^{\mathrm{I}}$ undertaking to Indians. Many people in the United States want an unequivocal, definite and unambiguous declaration for India. Therefore, if I were to take part in the Government, I should announce immediately at a certain date a day twelve months after the end of the Japanese war that we British shall wash our hands of India. I should announce that now, so that Indians may have plenty of time to get together and see how best they can work together.

【It means the release of political prisoners immediately on the understanding that they won't embark on civil disobedience as long as there is a war on. Thus we can prepare the ground for self-government. Now what kind of Government India wants?】 I do not think we should be too much hampered by differences in India. After all they are there, everywhere, as they are among our own people. But because we have differences nobody here wants foreigners to settle our own differences. That applies to India. It is for Indians themselves to settle their differences. It is not any of our business. I should, therefore, announce that twelve months after the Japanese war we shall abandon our responsibilities for India. I do not think we ought to insist on Dominion Status. The idea that India should become a dominion is futile and quite contrary to her geographical necessity. Other dominions had historical affinity with us, but India culturally has not and will not belong to us. Her affinity will be with Asiatic countries. Her history and culture are contrary to ours.

『Moreover, it is a pity to ignore one most important factor. It is this that the Dominion Status gives the right to secede and everyone knows Indians will ex-

${ }^{\text {I }}$ [A correction of the texts, which both have "keep up undertaking". There is other internal evidence that Russell did not proofread the report and that, indeed, he did not read from a prepared text. (Ed.)] 
ercise it and use it to quit the Empire. Make no mistake about it, so why should we have this futile process when we know jolly well that India will get out of the Empire. At least you will get a situation similar to Southern Ireland when the Irish were given nominally a Dominion Status, though for all practical purposes this has done no good to anybody. Irishmen are outside the Empire except for their passports only which facilitate their coming to Britain.

I do not mean to say that nobody should have responsibility after our decision to abandon India. There ought to be an international authority which will look after the interests of all nations except of course the big nations which can keep on behaving as badly as they want. This international authority should apply to India primarily to exercise and prevent aggression against other countries. For instance, we should use this international authority if Poland goes on an aggressive war against Russia. We do not want military minorities anywhere seizing power with unconstitutional manner. If an international authority exists it should intervene in a civil war in India. If such a thing were to happen, the British have no special right to claim a title for intervening.』

India belongs naturally to other Asiatic countries rather than western. Her ties with Britain are more artificial than her ties with China. The domination of the White Man over the rest of the world since the sixteenth century is coming to an end. It will not go on any more in Asia which is awake. I am convinced of that. Our domination came into being as a result partly of our voyages, partly by a skilful use of commerce and partly as a result of science. As India develops industrially she will also develop as a military power. The era of White domination will not last. It cannot be revived. White domination has made it impossible for a stable world. You cannot have peace in the world secured as long as some people want to keep themselves in power. There will be hundred and one injustices in the world as a result of this domination. The other side has a feeling of hatred and contempt for those who dominate. Until you get approximately an equal standard in East and West you cannot go on. 